\title{
Surfaces
}

\section{HIROSHIMA, THE VIETNAM VETERAN'S MEMORIAL, AND THE GULF WAR: POST-NATIONAL SPECTACLES}

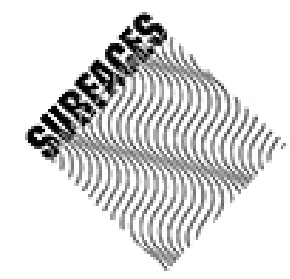

\section{Donald E. Pease}

Volume 4, 1994

SUR L'ÉPISTÉMOLOGIE DE LA GUERRE FROIDE

ON COLD WAR EPISTEMOLOGY

URI : https://id.erudit.org/iderudit/1064964ar

DOI : https://doi.org/10.7202/1064964ar

Aller au sommaire du numéro

Éditeur(s)

Les Presses de l’Université de Montréal

ISSN

1188-2492 (imprimé)

1200-5320 (numérique)

Découvrir la revue

Citer cet article

Pease, D. E. (1994). HIROSHIMA, THE VIETNAM VETERAN'S MEMORIAL, AND THE GULF WAR: POST-NATIONAL SPECTACLES. Surfaces, 4.

https://doi.org/10.7202/1064964ar
Résumé de l'article

Situant son propos dans le contexte de la transformation actuelle des structures globales du pouvoir, l'auteur offre une analyse théorique et historique des représentations que se font les États-Unis d'eux-mêmes ainsi que de leurs Autres. Prenant pour point de départ la guerre du Golf, il examine les récits nationaux de désastres nucléaires, le syndrôme du Vietnam, et l'érrection du « Vietnam Veterans Memorial ». Il conclut en interprétant l'affaire Rodney King comme ayant réactivé une mémoire divergente que l'image d'un Nouvel Ordre Mondial ne parvient pas à intégrer.
Copyright (C) Donald E. Pease, 1994

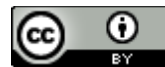

Ce document est protégé par la loi sur le droit d'auteur. L'utilisation des services d'Érudit (y compris la reproduction) est assujettie à sa politique d'utilisation que vous pouvez consulter en ligne.

https://apropos.erudit.org/fr/usagers/politique-dutilisation/ 


\title{
HIROSHIMA, THE VIETNAM VETERAN'S MEMORIAL, AND THE GULF WAR:
}

POST-NATIONAL SPECTACLES

Donald E. Pease

\begin{abstract}
In the context of changing structures of global power, this essay offers a theoretical and historical analysis of prevailing U.S. representations of itself and its Others. Taking as its point of departure the Gulf War, it examines the national narratives of impending nuclear desaster, the Vietnam syndrome, and the erection of the Vietnam Veterans Memorial. It concludes by interpreting the Rodney King incident as the activation of an alternative memory that cannot be subsumed by the image of a New World Order.
\end{abstract}

\section{RÉSUMÉ}

Situant son propos dans le contexte de la transformation actuelle des structures globales du pouvoir, l'auteur offre une analyse théorique et historique des représentations que se font les États-Unis d'eux-mêmes ainsi que de leurs Autres. Prenant pour point de départ la guerre du Golf, il examine les récits nationaux de désastres nucléaires, le syndrôme du Vietnam, et l'érrection du $<<$ Vietnam Veterans Memorial $>>$. Il conclut en interprétant l'affaire Rodney King comme ayant réactivé une mémoire divergente que l'image d'un Nouvel Ordre Mondial ne parvient pas à intégrer. 
In the two years since the war's conclusion, media coverage of the Persian Gulf War has elicited as much critical commentary as the U.S. foreign policy authorizing the war.[1] Ambivalence over the appropriate focus results in part from the official representations that tended to conflate incidents of war with their means of representation. From the outset, the Gulf War was constructed as a military enterprise designed on the one hand, to forestall Iraq's agression against Kuwait and, on the other, to solicit, following the breakdown of the Cold War consensus, the public's spontaneous consent to an alternative enframement of historical events.

The Cold War's authority as a consensus formation depended upon a dual capacity: to identify internal dissension as a threat to the national security and to recharacterize such dissension as the work of the National Other, the Imperial Soviet whose global ambitions enabled an extension of the Cold War's powers of enframement to the entire globe. When it operated outside U.S. borders, the Cold War configured the globe within a superordinate binarism that supervised a range of vertical rankings (North/South, First World/Third World, male/female, white/black, EuroAmerican/ other) within and without the territorial U.S. borders. Because it always misrepresented internal divisiveness as if it were an external dualism, however, the Cold War framework was inherently unstable. It constituted a coherent national identity out of diverse constituencies whose differences could only be partially and unevenly repressed through their projection onto a wholly exterior oppositional power. Throughout its forty-five year rule, the Cold War's binary organization of the ideological differences between the U.S. and the U.S.S.R. depended upon the successful repression of a multiplicity of internal differences between heterogeneous social groups but also within individual citizens. Overall, the coherence of the national identity was the result of a highly complex process. It entailed the condensation of these heterogeneous social materials into a single foregrounded entity, a nationality whose stability had to be constantly renegotiated in relation to such different matters as race, class, gender and ethnicity.

The three proper names in the title designate crucial phases in the epoch of Cold War rule and represent different symbolic resolutions of this constitutive instability. Individually and collectively they designate monumental national memories expressive of an ahistorical supra-national essence as well as traumatic historical materiality unassimilable to the grand narrative of U.S. history.

As the medium through which the State Department had projected terrifying images of the Communist menace onto the National Imaginary, Hiroshima 
oversaw, in the years 1945-1968, the subordination of political dissent to the policy of containment abroad, and the emergence of liberal anti-communism as the new civil religion at home.

The Vietnam Veterans Memorial bears witness to two extremely different orientations in the breakdown, during the Vietnam era, of the Cold War's powers of enframement. After the anti-war movement successfully recast the U.S. rather than the U.S.S.R. as the aggressor in Vietnam, it was no longer possible to misrecognize domestic social protest as the work of the "other" superpower. From 1968-1980, patriotic nationalism was displaced with critical scrutiny of U.S. imperialism.

Following the 1980 election, the Reagan administration proposed a different understanding of the Vietnam era. It renamed the unwillingness to intervene in the Third World a national pathology, the "Vietnam syndrome" and associated this failure with other forms of social unrest. Characterizing the social contradictions that after the Vietnam War had become open to analysis and resistance, as likewise symptomatic of the nation's loss of resolve, Reagan activated widespread nostalgia for Cold War certitudes. In campaigning against the Vietnam syndrome, Reagan summoned U.S. citizens to their collective refashioning in the transhistorical image of the self-reliant individualist he had previously represented in his screen roles, then deployed images from the Cold War in an ongoing war of position he waged on heterogeneous social sites. Reaganism set middle class blacks against the black underclass, pro-life feminists against abortion advocates, straights against gays, U.S. workers against laborers from the Third World, etc. When he baptized the Vietnam Veterans Memorial an official commemoration of the victims of world communism, Reagan accomplished a resolution of these self-divided and heterogeneous social spaces into a chain of interlinked connotations that reconstituted the National Imaginary out of this collective memory of the Vietnam era.

To secure the linkage between the pervasive social logic whereby he reconstituted a unified national identity out of diverse constituencies, Reagan had to overcome internal adversity by reprojecting the object of social unrest onto a revivified National antagonist, the Evil Empire. But with the end of the Cold War in 1990, the Bush administration had lost the National Other against which and through which Reaganism had articulated its "deterrence" hegemony. As a consequence, Bush was faced with the task of reconfiguring the iconography of Cold War rule within the objectives of a New World Order. To accomplish this task, the Bush administration staged a military victory in Iraq to celebrate the end of the Cold War and resuscitate its power to rule. 
In his effort to solidify the Reagan Administration's social formation, the Bush administration found in Saddam Hussein a new enemy in whose image U.S. publics were encouraged to misrecognize their internal differences. To complete the nation's recovery from the Vietnam syndrome, the State Department specified its origins in the anti-war consensus. The Bush administration, in its efforts to overcome the Vietnam Syndrome for which it had found the media largely responsible, thereafter not only limited media access to coverage of the Gulf war, but struggled to convert the events actually taking place during the war into a virtual reality of purely symbolic forms -- instruments for the construction of a new consensus --rather than historical facts.

Following reports of Hussein's nuclear arsenal, Bush reinscribed the nation's governmentality in the totalizing image of its strategic defense against nuclear terror. In this alternative visual field, incidents of war could not be disassociated from surveillance technology. Upon identifying the public's gaze with the war machine's surveillance apparatus, Operation Desert Storm shortcircuited the relay between events and their factual observation. By depriving individual viewers of critical distance, the official representations elided their historical witness, there. The surveillance system thereafter systematically displaced the negative images associated with the Vietnam War -- body bags, critical commentary, civilian casualties, jungle warfare, faulty technology, guerrilla insurgents -- and condensed the remainder to the now of the New World Order.

A significant consequence of this loss of a critical standpoint was a disregard for documentable facts about that war. [2] In an effort to keep track of what he calls the "incontrovertible" historical facts, Christopher Norris has provided the following succinct account of that documentary record:

1 ) that Saddam Hussein was brought to power and maintained over a long period by US intelligence and 'long-arm' strategic agencies; 2) that his regime was backed up until the very last moment by constant supplies of weapons and resources (not to mention diplomatic support) provided by the US and other Western powers; 3) that this invasion of Kuwait was prompted --or at least given what appeared to be the green light--by indications that the US would not intervene since it also wished to push up the oil-prices by exerting pressure on Kuwait; 4) that the Gulf War was fought first and foremost as a war of retribution against an erstwhile ally who had proved too difficult to handle; 5 ) that its conduct involved not only enormous military and civilian casualties but also -- contrary to professed 'Allied' waraims -- a full-scale campaign of aerial bombardment launched against electricity generating stations, water-supply systems, sewage disposal plants, and other components of the urban infrastructure whose collapse could be predicted to cause yet further death and suffering through the breakdown of emergency services and the spread of infectious diseases; 6) 
that the attacks on retreating Iraqi forces (along with civilian hangers-on and hostages) continued to the point where any justifying talk became merely a cover for mechanized mass-murder; and 7) -- still within the realm of documentary evidence -- that the war might well have been averted had the 'Allies' held out against US pressure and listened to those well-informed sources who argued that sanctions were already (in early January) taking their toll of Iraqi war-fighting capabilities.[3]

In the remainder of this essay I shall not supply further critical commentary but briefly trace multiple logics at work in conflicting representations of that war as well as those at work in other ("Hiroshima" and the "Vietnam Veterans Memorial") substitutive objects of Cold War governmentality, includin their power, on the one hand, to enforce its rule and, on the other, to effect a strategic reversal. The massive scale of eventuation inferable from their trajectory calls attention to the difficulties these names proposed individually and collectively to Cold War historicity, which had developed sufficiently to include contradictory attitudes. I shall not be concerned primarily with a critical account of the imperialist ideology informing the Cold War, but would remark at the outset that the Cold War's powers of global enframement constituted in the United States' foreign policy of the last forty-five years the basis for such imperialist practices as the "formal" accumulation of territories, populations and markets, the control of economies, as well as the projection of political ontologies. In decomposing heterogeneous temporalities under the horizon of its binaristic totalization, Cold War historicity expropriated plurality from history, reducing spatiotemporal differences to the homogeneous continuity of its contemporaneity, and historical signification to the double bind through which it becomes eventful.

As indicators of the unstable linkages between the plurality of histories each term connotes and the external antagonism onto which the Cold War had only partially projected them, the names "Hiroshima," "Vietnam Veterans Memorial" and "Persian Gulf War," disclose the susceptibility of Cold War totalizing historicity to a radical dismantling. When redescribed as unstable historical linkages, the second and third terms rehearse difficulties in commemoration and projection, respectively. The Vietnam Veterans Memorial was designed to restore to official national memory events which in fact undermined the assumptions informing the Cold War frame and the Gulf War "took place" as if to make apparent the otherwise phantasmatic "end of the Cold War." These brief observations attest to the fact that each one of these terms harbors ongoing contestations over its significance.

In denying such alternative historical significations, the Cold War proposed a categorical reductionism that sublated all other possible meanings into one or another of its supervisory binarisms. In order to bear critical witness to a specific occasion wherein one of these terms, in coming delinked from its Cold War framework, released a plurality of alternative memories of its 
historical significance, I shall analyze the so-called "Rodney King Affair," as an overdetermined counter memory of the Gulf War.

When it was released on March 3, 1991, this eyewitness video of Los Angeles police officers brutally clubbing an unarmed black citizen filled in blanks -- images of wounded civilians, excessive military force, ground combat-- that during the Gulf War had been projected as visible absences. As it thus returned these repressed images of war to national visibility, this post-war spectacle restored as well the elided distance between facts and representations necessary for a critical standpoint.[4] With its interruption of U.S. spectators' previous identification with the surveillance apparatus of the New World Order, this post-national spectacle reversed the effects of U.S. disavowal of colonialist brutality in the Gulf, and thereby enabled heretofore denied alternative knowledges to emerge as active forms of political resistance.[5] In place of the images transmitted from Baghdad, a Third World spatiotemporal field, in an operation Homi Bhabha has analyzed intensively, was relocated to Los Angeles:

It is a process whereby the look of surveillance returns as the displacing gaze of the disciplined, where the observer becomes the observed and the "partial" representation rearticulates the whole notion of [national] identity. [6]

When rearticulated in relation to such unofficial scenes, the three proper names in the title render quite visible an otherwise occluded asymmetry between the National Security State and an heterogeneously constituted nation-state. Involved in a mimetic rivalry with the nation-state over appropriate representation of the United States, the National Security State has depended for its legitimacy on the generalized fear of nuclear holocaust which followed in the wake of Hiroshima. From 1945 until President Bush's January 28, 1992 State of the Union Address, the Cold War supervised the nation's post-war recovery by securing the citizenry's willingness in peacetime to submit to wartime discipline. The beneficiary of this collective surrender of will was "the National Security State," whose governmentality derived from Hiroshima. Not Hiroshima the actual the historical event that took place on August 6, 1945, at the conclusion of the Pacific campaign and resulted in the deaths of over 100,000 Japanese soldiers and civilians, but Hiroshima as the possible fate of U.S. citizens if Soviet imperialism remained unchecked .

Because Hiroshima involved the near total annihilation of a civilian population, it was unassimilable to the assumptions underwriting a national narrative -- wherein the United States had always liberated a nation from the totalitarian designs of Soviet imperialism. "Ultimate" responsibility was thereafter projected onto the potential nuclear aggression of the Imperial 
Soviet, whereupon Hiroshima became a purely symbolic referent for a merely possible event and was reassigned the duty to predict an anachronistic event, the 'what "will have happened" had not the United States already mobilized the powers of nuclear deterrence against the Soviets.'

Unlike other historical anachronisms, this nuclear holocaust from the future anterior entailed the destruction of any recollective agency capable of recording its historical actuality. In the following passage Jacques Derrida explains the dizzying temporal status of such a nuclear holocaust whose future existence depends upon its anticipatory recollection from a present time, which is itself in danger of never being recorded as a memorable past:

Unlike the other wars which have all been preceded by wars of more or less the same type in human memory [...] nuclear war has no precedent. It has never occurred itself; it is a nonevent. The explosion of American bombs in 1945 ended a "classical" conventional war; it did not set off a nuclear war. The terrifying reality of the nuclear conflict can only be the signified referent, never the real referent (present or past) of a discourse or text. At least today, apparently. And that sets us thinking about today, our day, the presence of this present in and through that fabulous textuality [...] For the moment, today, one may say that a non-localizable nuclear war has not occurred; it has existed only through what is said of it, only where it is talked about. Some might call it a fable, then a pure invention: in the sense in which it is said that a myth, an image, a fiction, a utopia, a rhetorical figure, a fantasy, a phantasm, are inventions.[7]

As the no-place the United States might have become had it not proleptically opposed, as the precondition for the post-war settlement, the Soviet Union's nuclear capacity, Hiroshima also presignified the geopolitical fate of those nation-states which had not identified the paradigmatic event of the U.S. national narrative ("liberation from imperial aggression") as the "political truth" of their nationhood. The name of the always already displaced event which every other Cold War event at once deferred yet anticipated, Hiroshima held the place of what might be called the Cold War's Transcendental Signifier. Because Hiroshima will have taken place only if the terrible reality of an all-out nuclear war did indeed take place as such in some possible Cold War future, its historical "referentiality," at the conclusion of World War II would, according to the phantasmatic logic of the nuclear imaginary, also undergo derealization if the Cold War lost its future.

Just such a symbolic return from the future informed the specular logic of the Gulf War[8]: capitalizing on the uncanny temporality informing the Cold War, it was effected by a framing narrative which first disavowed any possible referent for Hiroshima within the U.S. national narrative and then 
identified Soviet totalitarianism as the potential historical agency for this non-event. In the image of the Saudi Desert, which recalled the testing ground before and the nuclear winter after the holocaust, Operation Desert Storm enacted a simulacral return to the site of the first atomic explosion at Alamagordo, New Mexico, at 5:29:50 a.m. on July 16, 1945. Following this ex-post-facto deactivation of the nuclear device Saddam Hussein was prevented from testing, the U.S. public was to have been relieved of a fortysix-year-old nightmare:

And so now [President Bush reassured the nation, in his January 28, 1992 State of the Union Address, for the first time in 35 (sic) years, our strategic bombers stand down. No longer are they on round-the-clock alert. Tomorrow our children will go to school and study history and how plants grow. And they won't have as my children did air raid drills in which they crawl under their desks and cover their heads in case of nuclear war. My grand-children don't have to do that and won't have the bad dreams children had once, in decades past. There are still threats. But the long, drawn-out dread is over. [9]

Bush drew upon this residual nuclear dread when he observed "that the veterans of the Gulf War were safer in the Middle East than in the streets of their own cities." [10] In correlating urban violence with Saddam Hussein's putative nuclear terrorism, President Bush was not simply referring to the dangers of street crime but to the continued threat of nuclear attack from Third World despots like Saddam Hussein. Bush thereby reanimated an understanding of civil defense that presupposed the sacrifice of urban population to the "first strike" capabilities of the enemy. Dean MacCannell has described succinctly this "internal" foreign policy as an aspect of the "nuclear unconscious":

Nuclear technology, even without another Hiroshima, has already had a profound impact on social structure and consciousness, perverting them both in discernible ways. Beneath the surface of fear, the supposedly unthinkable prospect of millions of deaths in the United States of America, one can find growing evidence of the desire to experience the bomb. The United States official policy of [...] sacrificing our cities [...] suggests that the configuration of every detail of domestic life in the United States is the product of a transformation of our foreign affairs into a quasi-military nuclear foreign policy.[11]

Following the supersession of the Cold War by the New World Order, the nuclear anxiety originating from Hiroshima was to be understood as if retrospectively crucial to the dismantling of the Cold War mentality it had engendered. As the actual historical enactment of the "spectacular annihilation" the Cold War at once affirmed yet denied, Hiroshima had 
acquired the U.S. public's spontaneous consent for the containment ideology of the Cold War epoch and a vivid justification for the policy of nuclear deterrence. As a national spectacle, Hiroshima had turned the entire U.S. social symbolic system into the afterimage of a collectively anticipated spectacle of disaster, a self-divided (rather than self-present) instant, that had always not yet taken place (hence always anticipated) but had nevertheless always already happened (in the lived experience of anticipated disaster).

The difference between the Cold War's phantasmatic ordering of events and social relations more usually attributed to the structure Guy Debord has called the society of the spectacle[12] entails a further transformation of the spectator. As the representation of anticipated total disaster, Hiroshima transfigured Cold War spectators into symbolic survivors of their everyday lives, able to encounter everyday events as the afterimages of ever-possible nuclear disaster. The spectacle of anticipated nuclear disaster activates a psychic logic able to convert events in everyday life into the screen memories of that unrepresentable scene. In the aftermath of disasters on the scale of Hiroshima, actual survivors could never have exchanged their experiences for already existing national images. Such exchanges would have rendered the absolute singularity of nuclear disaster more or less continuous with other cultural representations. In place of a generalized exchange, the Cold War derived its authority from the displacement of scenes of nuclear disaster, otherwise incommensurate with the official scenarios out of which the national narrative constructs its representations, with a global conflict. As a spectacle able permanently to deter the nuclear holocaust, for which it served as a screen memory, the East-West conflict reactivated the spectator in the national survivor, but also thereby authorized a division between what was representable and what was of necessity unrepresentable in the national narrative. As the official representation of an unrepresentable dimension of the national narrative, Hiroshima became the sociopolitical unconscious of the National Security State.

As compensation for the continuous non-eventuation of the nuclear holocaust, the National Security State was tacitly granted the power to perform illegal covert activities. In exercising the power necessary to impede nuclear war, the National Security State turned the U.S. publics' specular relations with nuclear holocaust into what Michael Paul Rogin has called their "vicarious participation" in the Cold War spectacle:

Most obviously, the specular relations to political life has implications for democratic governance. Spectators gain vicarious participation in a narrative that, in the name of national security, justifies their exclusion from information and decision making. Covert operations as spectacle purify domestic as well as foreign audiences, for they transform the political relation between rulers and citizens from accountability to entertainment... 
Vicarious participation in the spectacle of the covert secures in fantasy and preserves in fact the separation of those who plan from those who kill and are killed.[13]

When the Cold War scenario positioned Hiroshima within this social logic, it transmuted nuclear panic into the opportunity to stage a technological spectacle corroborative of the nation's invulnerability. An invisible but pervasive supplemental scene accompanying their daily experience, "this end of the world" Cold War scenario enabled U.S. citizens to re-experience everyday doubts, confusions, conflicts, and contradictions as the Cold War's power to convert indeterminacy into an overdetermined opposition. Paul Virilio has spelled out some of the political consequences of this interidentification of personal with national security:

There is no more need for an armed body to attack civilians so long as the latter have been properly trained to turn on their radios or plug in their television sets. No need for solid, laboriously moving bodies when their spectral images can be projected anywhere in an instant. From now on military assault is vaporous in time and the population's organic participation is no more than the irrational support of a technologistical supra-nationality, the final stage of delocalization, and thus of servitude.[14]

In its forty-five years, the Cold War can thus be said to have assumed two distinct aspects. It was both a spectacle capable of organizing national life and a paradigm capable of determining international politicy. Although these two cultural functions were certainly not equivalent, they were interlinked. As a spectacle responsive to the public's need for vicarious participation in the decision-making powers of the National Security State, the Cold War exhibited its powers of spectacular persuasion precisely in those historical moments when the Cold War as a paradigm failed to account for political complexities. When the Cold War as paradigm became productive of doubts, the Cold War as spectacle represented that doubt as itself a threat to the national security, and thereby effectively depoliticized the relations between U.S. citizens and their government. It displaced situations that citizens could change into an arena of decision-making wherein the unthinkable scenario of nuclear holocaust was a possible outcome. In functioning as a spectacle, then, the Cold War did not articulate the significance of political events but reduced them to the status of ever-possible nuclear afterimages (arguably the fate of every event in the Cold War epoch) in need of covert operations for their preservation.

The Cold War as paradigm confined totalizing oppositions to the work of the other superpower, but as a spectacle the Cold War identified its own totalization as that Other at work. The paradigm thereby reduced freedom either to the activity of positioning oneself within the structured opposition 
or to the "freedom from" the need to decide, and relocated the U.S. citizen within a spectacle in which all discussion had been decisively premediated, if not quite settled, and the only unfinished business was that of forming the "national character" through whom the paradigm could speak.[15] /pp.

$18-19 /$

I began this discussion of Hiroshima by describing its double register as at once the Signifier of the Cold War's powers of displacement as well as the counter-memory belonging to an order of events other than the official history regulated by the National Security State. But thus far I have devoted all of my attention to the Cold War's capacity to deny the difference between its powers of enframement and this different order of historical eventuation. As long as it functioned as the Signifier of the Cold War's power to appropriate and redescribe the agency responsible for nuclear holocaust, Hiroshima legitimized the suspension of the system of checks and balances underwriting the U.S. Constitution and authorized, in the name of National Security, a shadow government comprised of unelected officials engaged in covert activities and undeclared wars. When successfully waged, these wars redeployed the containment power inherent to the Cold War as the frame necessary for the unfolding of a formulaic drama (of a heroic democratic people overcoming a despotic, totalitarian power) whose entertainment value derived from a collective desire to find nuclear panic reduced to the dimensions of conventional warfare.

Traditionally the beneficiary of such Cold War spectacles was the National Security State, but during the Vietnam War the Cold War's failure to correlate acts of war with this formulaic scenario resulted in collective national trauma. Combat veterans of the Vietnam War delegitimated the National Security State's authority as in violation of rules of International Law, and rendered suspect the Cold War as the putative agency of ideological identification. Intense criticism of U.S. foreign policy during the Vietnam War explicitly associated military atrocities against civilian populations with Hiroshima. In an article which predicts obliquely the Gulf War, Marita Startkin has described the Vietnam Veterans Memorial as an unsuccessful attempt to overcome the national trauma resulting from actions incompatible with the prevailing representations in the national narrative:

The incommunicability of Vietnam War experience has been modified by the communicability of its memorial. Yet we cannot understand the role played by this memorial, by its difference as a memorial, unless we understand what made the war it memorializes different. In the Vietnam War the standard definition of warfare had no meaning. This was a war in which the enemy was not always known, and in which the master narratives of "free" world versus communism and firstworld technology and third world "peasantry" were no longer credible. The rupture in history made by the Vietnam War is... [of] the ability of this country to impose its will on others. [16] 
The monument commemorated what was commonly referred to as the Vietnam Symdrome, the loss of the nation's resolve to intervene overseas. When understood as an effort to disremember the Vietnam War, Operation Desert Storm could be re-described as a deferred reenactment and subsequent working through of the traumatic events in this "unfinished war," and an attempt to relegitimize the foreign policies subject to intermittent re-evaluation in the aftermath of Vietnam (and Hiroshima). If, Marita Startkin has concluded, "the memorial acts as a screen for projections of a multitude of memories"(137), the Gulf War provided the figures capable of being projected onto that screen. When the United States failed to win the Vietnam War, the national spectacle lost the power to screen the memory of nuclear holocaust and, as a direct psychological consequence of this failure, startling numbers of Vietnam Veterans identified themselves with the survivors of Hiroshima. By way of a growing number of testimonials, autobiographies, and improvised narrative accounts, these combat veterans did not sacralize the nation's military violence by effacing its signs, but bore witness to images of war (charred bodies, dismembered limbs, eyeless skulls) that were utterly heterogeneous to the national narrative. But the technology of warfare displayed in the Gulf exceeded the needs of the individual soldiers. Unlike their predecessors in Vietnam, combat soldiers in Desert Storm seemed surplus appurtenances whose bodily integrity was assured rather than betrayed by a War Machine productive of a new chain of national memories, replacing the bodies in pain recalling Vietnam with bodies shielded from danger. As the public watched the war on television, the traumatic materials inherited from Vietnam seemed to have been "worked through" in the hyperreality of the Iraqi Desert and thoroughly acted out of the national psyche.

As a "supplemental" recollection of the Vietnam War, the Gulf War can be described as having completed the screen memories projected onto the Vietnam Veteran's Memorial. But it also stirred up traumatic materials (including the recollection of mass death at Hiroshima), those memories that had been only partially repressed. By commemorating the War, the Vietnam Veteran's monument rendered it continuous with other national scars. In the Gulf War the Bush administration tried to project onto that screen of memorability such exemplary figures as the Vietnam Veterans Norman Schwarzkopf and Colin Powell. Whereas the Veterans' Memorial had screened out negative images of Vietnam Veterans, the Saudi Desert, projected over 500,000 official substitute images of U.S. men and women whom the U.S. military had shielded from enemy attack.[17]

In linking the Gulf War to Hiroshima by way of the Desert Shield the Pentagon had hoped to represent the nation as if it too were immune to nuclear attack. The U.S. public, the pictures transmitted from the desert suggested, should understand itself as liberated from the forty-six years in which it was the hostage of nuclear panic. But in its contradictory linkage of the Gulf War with Hiroshima, the Vietnam Veteran's War Memorial 
reactivated a way of remembering these forty-six years quite different from the selective amnesia authorized by the New World Order. W.J.T. Mitchell indirectly alluded to this alternative memory when he shrewdly observed that the power of the Memorial derives from its violation of the Cold War's conventional means of repressing (and expressing) violence:

The Vietnam Veteran's Memorial is antiheroic, antimonumental, a V-shaped gash or scar, a trace of violence suffered not of violence wielded in the service of a glorious cause (as in the conventional war memorial). It achieves the universality of the public monument not by rising above its surroundings to transcend the political, but by going beneath the political to the shared sense of a wound that will never heal, or (more optimistically) a scar that will never fade. Its legibility is not that of narrative: no heroic episode such as the planting of the flag on Iwo Jima is memorialized, only the mind-numbing and undifferentiated chronology of violence and death catalogued by the fifty-eight thousand names inscribed on the black marble walls. The only other legibility is that of the giant flat $\mathrm{V}$ carved in the earth itself, a multivalent monogram or initial that seems uncannily overdetermined. Does the V stand for Vietnam? For a Pyrrhic "Victory"? For the Veterans themselves? For the Violences themselves?[18]

Throughout this account, Mitchell draws attention to the difference between the figures it memorializes and their unassimilability to the national narrative. As does Hiroshima, the Vietnam War occupies the site wherein historical facts differ from their conflicting representations. As an undisputed fact, the Vietnam War refers to the historical events which took place during the U.S. occupation of South Vietnam between 1954 and 1973. As a cultural phenomenon, the Vietnam War refers to the massive transformation in the nation's self-understanding which took place during those same years. In American Myth and the Legacy of Vietnam, John Hellman explained this change as the nation's loss of its mythological rationale. That mythology which originated with James Fenimore Cooper's Leather-Stocking Tales retold the story of America's origination in the savage wilderness and its violent regeneration through its many campaigns against the empire. But Vietnam brought this mythology to a conclusion when, instead of finding themselves able to take possession of their Vietnam experience by projecting this "inner romance" upon it, U.S. combat soldiers entered into a psychic landscape "that overwhelmed the American idea of frontier" [as liberated territory].[19] When televised on the evening news, incidents in the Vietnam War refused to become referents in the composite national event which cross-identified Columbus' discovery of the New World with the American colonists' successful revolution against the British Empire. Unlike previous geographical sites on which the American Revolution was successfully restaged, Vietnam resisted this frame. Because the U.S. government could not provide a coherent justification for the American presence in Vietnam, combat soldiers, who lacked a moral rationale for their actions lost the power ethically to discriminate between war crimes and incidents of war. 
Their individual collective difficulties resulted in a profound change in the dominant cultural image of the American soldier, turning the heroic adventurer into an emotional cripple. This transformation in the agent of war was accompanied by related changes in cultural representations of the scene of battle and the narratives which appropriated it to the national mythology.[20] The belief structures informing the Vietnam combat veterans' understanding of the national mythology of war were incommensurate with their wartime experiences. Because their experiences could not gratify the national appetite for myth, they instead exposed the assumptions informing the national mythology, as well as the interests served by these assumptions. Their inability to identify the military's atrocity producing activities with the official mythology led the vast majority to construe Vietnam as an unjust war. That construal resulted, in turn, in a reconceptualization of Hiroshima, as the first traumatic symptom of the Vietnam syndrome.

In an essay he published in the aftermath of the Russell International War Crimes Tribunal, Noam Chomsky designated "genocide" as the basis for their historical association:

Hoopes [a former Under-Secretary of the Air Force who resigned after the Tet Offensive] does not tell us how he knows that the Asian poor do not love life or fear pain, or that happiness is probably beyond their emotional comprehension. But he goes on to explain how "ideologues in Asia" make use of these characteristics of the Asian hordes. Their strategy is to convert "Asia's capacity for endurance in suffering into an instrument for exploiting a basic vulnerability in the Christian West." They do this by inviting the West "to carry its strategic logic to the final conclusion, which is genocide..." At that point we hesitate, for remembering Hitler and Hiroshima and Nagasaki, we realize anew that genocide is a terrible burden to bear.[21]

Here and elsewhere in his analysis of the war, Chomsky refused official history's explanations of events. Identifying the characteristics assigned indiscriminately to all "Asian masses" as a symptom of "official racism," Chomsky interlinked this policy with U.S. efforts to construct the Japanese people as the nation's "official /pp. 24-25/ enemy" during World War II, and he associated the policy of genocide in Vietnam with the mass destruction of civilian populations in Hiroshima and Nagasaki. Following these recharacterizations, Chomsky argues that as the agency responsible for these war crimes, the National Security State should be tried for violations of International Law.

When combat soldiers involved in action in Vietnam struggled after the war to disavow their complicity in war crimes, their efforts only implicated them 
further in a chain of compulsive violence. In his commentary on the war, Jean-Paul Sartre provided the following account of their reaction-formation:

They [the American soldiers] came to save Vietnam from "communist aggressors." But they soon had to realize that the Vietnamese did not want them. Their attractive role as liberators changed to that of occupation troops. For the soldiers it was the first glimmering consciousness. "We are unwanted, we have no business here..." They vaguely understand that in a people's war, civilians are the only visible enemies. Their frustration turns to hatred of the Vietnamese; racism takes it from there. The soldiers discover with a savage joy that they are there to kill Vietnamese they had been pretending to save. All of them are potential communists, as proved by the fact that they hate Americans. Now we can recognize in those dark and misled souls the tenth of the Vietnam War: it meets all of Hitler's specifications[...] Whatever lies or euphemisms the government may think up, the spirit of genocide is in the minds of the soldiers. This is their way of living out the genocidal situation into which their government had thrown them.[22]

According to Sartre's account, these combat soldiers constructed a false-self system which they divided off from their experience of the genocidal structure of the war. This false self (the figure in these soldiers only "pretending" to save the Vietnamese people from communist aggressors), however, was the only subject the United States government officially recognized. In his groundbreaking work with Vietnam Veterans, Robert Jay Lifton discovered profound similarities between the combat veterans' collective experiences of social abjection - -- ontological insecurity, desymbolization, general distrust of the counterfeit nurturance of the environment, psychic numbing, flashbacks to the experience of death immersion, psychic disconnections between affect and experience, shock syndrome -- and those of hibakusha, the survivors of Hiroshima, who were the subject of Death in Life. Neither the experiences of hibakusha nor the veterans Lifton examined could be represented in the image repertoires of their respective national narratives. As psychic materials in excess of any narrative's power to derive significance, these profoundly disturbing experiences remained unforgettable and unrepresentable somatic symptoms, and returned hibakusha and Lifton's Vietnam Veterans alike to the respective scenes of their traumas. Unable to surrender their past experiences to a narrative enchainment able to redescribe terror as valor, pain as courage, mutilation as integrity, and thereby transmute physical distress into the abstractions cultures reward, the survivors of Hiroshima as well as the Vietnam War, Lifton explained, instead felt absolutely disassociated from their culture's social symbolic orders. Without belief in the official narratives with which the government justified its Vietnam policy, the Vietnam Veteran became, in the national mythology, the representative of a spectacle of atrocity -- napalming, holocaust, assassination, torture -the official scenario could not recuperate. 
The Vietnam Veterans, in remaining unassimilable to the paradigmatic event structuring the national narrative, activated an order of discourse asymmetrical with the culture's habitual self-explanation. Their inability to justify their atrocity-producing activities in Vietnam with the imperatives of the National Security State can be understood as partly responsible for the national adjudication of the difference between that shadow government and the U.S. Constitution called the Watergate Trial. As it apprised the nation of the difference between its two constitutions (the U.S. Constitu-/pp. 26-27/ tion proper and the emergency measures of the National Security State) that trial also suspended the Cold War's power to enframe historical events.

The construal of the Vietnam War as unjust retrospectively enabled revisionist understanding of Hiroshima as the first symptom of what was to be called the Vietnam syndrome. With the following observations Robert Lifton proposed the My Lai massacre as the historical syntax able to bring Hiroshima into grammatical combination with the Watergate scandal as well as the Vietnam War:

At My Lai the atrocity involved the killing of five hundred non-combatants, Watergate involved subverting the electoral process -- an atrocity of its own -- in a way that makes more likely the kind of military atrocity that occurred at My Lai [...] Like Hiroshima and Auschwitz, My Lai is a revolutionary event: its total inversion of moral standards raises fundamental questions about the institutions and national practices of the nation responsible for it [...] One finds in Watergate and My Lai a simplistic polarization of American virtue and communist depravity [...] There was a self-perpetuating quality to the whole Watergate style [which also applies to My Lai and Hiroshima]. One had to keep on doing more things to prevent a recognition of what one had done from reaching oneself or others.[23]

Because such veterans as these experienced themselves, on their return home, as the objects of a generalized ostracism (for their failure to fulfill the imperatives of the national narrative and "liberate" Vietnam from totalitarian aggressors) comparable in its effects to social stigmatization, they reinvented themselves as U.S. relatives of Japanese hibakusha.[24] Others represented the cause of the Vietnam people against the imperatives of the U.S. government, and they struggled for the rights of Asian minorities. Having discovered the Vietnamese survivor in their own psychic experience of the war, many veterans became anti-war dissidents, in open conflict with a government (and a public) which had betrayed them by refusing to understand their predicament. In assigning the moral responsibility both for the war's atrocities and their inability to recover to the National Security State, these Vietnam Veterans became representatives of the political alternative to the Cold War mentality known as the Vietnam syndrome. 
Astonishingly, that syndrome informed official foreign policy until Ronald Reagan took office in 1980 with an understanding of the cultural significance of the Vietnam Veteran quite different from Lifton's. Throughout his presidency, Reagan recharacterized the combat soldiers in Vietnam as prisoners of an anti-war sensibility which had deprived the U.S. public of its patriotic pride. His motives for commissioning the erection of the Vietnam Veteran's Memorial entailed the psychological rehabilitation of these combat veterans and the nation's recovery from the syndrome they represented. Reagan never wavered in his intention to return the United States to the psychological euphoria of the pre-Vietnam Cold War:

Restoring America's strength has been one of our Administration's highest goals. When we took office, we found that we had ships that couldn't leave port [and] planes that couldn't fly [...] In the last five and half years we've begun to turn that desperate situation around. We've restored the morale, the training, and the equipment of our armed forces. And let me just say that around the world and here at home, I've met many of our young men and women in uniform over the last several years. It does something to you when you're standing up there on the demilitarized zone in Korea and a young fellow standing there in uniform says, "Sir, we're on the frontier of freedom". [25]/pp. 28-29/

The Wall, as the Vietnam Memorial was commonly called, was to have represented Reagan's new frontier of freedom. What W.J.T. Mitchell described as a scar, memorializing the fact that the Vietnam experience had been separated from any other official form of recollection, Reagan understood contrastively as a badge of courage, a national war wound representative of many acts of valor deserving of national commemoration. Erected during the second year of Reagan's presidency, the monument was intended to erase the negative chain of recollections and activated as the official national memory of the Vietnam era, the Vietnam P.O.W. representatives of an imprisoned American citizenry, struggling to return to the political certitudes of World War II.[26] The War Memorial became the gigantic screen onto which U.S. citizens were encouraged to project their collective wish to recover national pride.

The agency responsible for the success of this screen memory was not Ronald Reagan the President but Ronald Reagan, the actor, who provided the spectator public with representative heroic actions -- "freedom fighting" in Nicaragua, the bombing of Libya, the invasion of Grenada -- and encouraged U.S. citizens to realign themselves with the doctrine of American Exceptionalism and the moral imperative to fight a Just War. One result of this realignment was the disavowal of any similarity between U.S. combat veterans and Japanese hibakusha. 
Being recalled to the imperatives of the Cold War entailed the nation's collective amnesia of Vietnam and Watergate as condensed connotations of Hiroshima, the "event" incommensurable with the Cold War frame narrative. As long as the Cold War scenario successfully recoded these historical events into its frame of reference, this collective amnesia remained in force. But in the last two years of the Reagan presidency, glasnost and perestroika threatened to bring the Cold War itself to an end, thereby depriving Reagan of his habitual way of explaining away such illegalities as the arms for hostages deal which surfaced in the Iran-Contra hearings. If we understand the Gulf War as a spectacle in which the pentagon aspired to represent the end of the Cold War as a U.S. victory, we can also understand it as the Bush administration's effort to justify the National Security Council's role in Irangate. The Gulf War was after all a way of diverting the national attention away from covert operations and redirecting it to a purely symbolic war.

In trading arms to Iran in exchange for money to conduct unauthorized wars in Latin America, the National Security State had turned an Ideological Enemy into an Ally in an illegal war. Because of this and related political contradictions it brought into the open, Irangate recalled Watergate and encouraged an understanding of the Reagan presidency as comparable with Nixon's. Without the Cold War to justify its covert operations, the National Security State had become the subject of more critical scrutiny than any other period since Vietnam. To recover the integrity of the National Security State, the Bush presidency staged a scenario which depended upon "arms for hostages" as its grounding rationale. As combat soldiers returned home from the Gulf, they became representative as well of the hostages released from Lebanon and less directly of the national citizenry released from the Cold War.[27]/pp. 30-31/

Following the U.S. military's systematic disarming of Saddam Hussein's nuclear capability, the U.S. public was invited to return to the Alamagordo Desert in 1945 but by way of the Saudi Desert in 1991 and thereby to witness the removal of the Cold War from the U.S. national narrative, and its miniaturization as the discourse exchanged by the principals in the Middle East. Instead of remaining mnemically bound to the traumatic historical materials -- the Dresden and Tokyo fire-bombings, the Cuban Missile Crisis, My Lai, Three-Mile Island, Chernobyl, the Iranian Hostage Crisis -- secreted in the Cold War mentality, official coverage of the Gulf War "worked through" Cold War hysteria by repeating all of these events in the infinitely fast-forward of an "end of History" scenario, understood this time as an overtaking of the Cold War past by way of a U.S. future, which rediscovered the Cold War in an underdeveloped temporality (the Middle East) understood as historically incommensurate with the New World Order. In refinding the Cold War in Kuwait's relationship with Iraq (rather than the 
United States' with the Soviet Union), the televisual public might have undergone what could be called collective para-amnesia. It was, as these representations suggested, to remember to forget its own Cold War history by learning to remember Middle Eastern history in the terminology of a miniaturized Cold War.[28]

With the compulsive repetition of the troops' triumphant homecoming (from World War II, Korea, Vietnam, Grenada, Panama as well as the Cold War), the U.S. should have entered the New World Order with the same ideological assurance that had been accrued after World War II, and the Cold War was to have been recycled as the history of the Middle East in the epoch of Pax Americana.[29] Able to see everything about the enemy without being seen, S.D.I. was to have turned each viewer into an agent of a Trans-National Security State, with surveillance responsibility for the globe. Invulnerable because invisible, this trans-national consciousness was to have enabled viewers to transform Iraq into a peripheral U.S. border and the Middle East (as well as every other "developing" nation) into the United States' political unconscious.

But, as I have already argued, the concrete fantasy which underwrote the Gulf War entailed the projection of moral responsibility for Hiroshima onto Saddam Hussein and the symbolic disavowal (in S.D.I.'s systematic dismantling of Hussein's nuclear capability) of Hiroshima's ever having actually taken place. Through this symbolic undoing of the United States' role in the forty-five-year Cold War, Operation Desert Storm repositioned the nation in the aftermath of World War II, a "war to end wars," and assigned it the responsibility for preventing nuclear wars in the future. But since the United States was in historical fact the only nation ever to have used a thermonuclear device in wartime (and would have, and for the same ostensible reason [to save U.S. lives] it used, once again in the struggle with Hussein), this denial of responsibility exposed the United States' undeterred preeminence as a version of the Imperial Power its national narrative was sworn to oppose. Which is to say that in the absence of the enemy Superpower onto whom the United States was used to assigning responsibility for its crimes, the United States had become its undeterred Other in the New World Order.

This historical fantasy depended upon the selective forgetting of the criticism directed against the Vietnam War as well as a new national mythology the quest for MIA's held captive (in Vietnam, Korea, the Soviet Union) since World War II. As "hostages" released at the conclusion of the Cold War, MIA's fostered an understanding of the nation itself as a hostage released after a forty-six-year captivity. The hostages released after the Gulf War fostered this identification. 
At about the same time as the war's conclusion, however, the Rodney King incident activated an alternative memory. When the nation's public gaze was directed inwards at the spectacle of a helpless black male beaten senseless as the result of a police action, the Gulf War lost its mandate to project internal dissension onto an external antagonism. The incident effectively detotalized the New World Order and triggered in the wake of this displacement a historical conjuncture discernible in the chain of contrary historical associations it enabled.[30] Reports of the rape of women in the U.S. military replaced Hussein's "rape of Kuwait," disclosures of the Bush administration technological assistance both before and during the war severely compromised official accounts of Saddam Hussein's "secret" nuclear device, news of friendly fire in the Gulf recalled Vietnam, the yellow ribbons of endless homecomings were replaced following the first jury verdict with riots in South Central Los Angeles and purple ribbons signifying "No Justice, No Peace." Operation Desert Storm became Iraqgate. Bush lost the 1992 election.

Mike Davis underscored the historical dimensions of this alternative memory with the following observations about the Rodney King affair:

The balance of grievances in the community is complex. Rodney King is the symbol that links unleashed police racism in Los Angeles to the crisis of black life everywhere, from Las Vegas to Toronto. Indeed, it is becoming clear that the King case may be almost as much of a watershed in American history as Dred Scott, a test of the very meaning of the citizenship for which African Americans have struggled for 400 years -- as a veteran of the 1965 riot said while watching SWAT teams arrest some of the hundreds of rival gang members trying to meet peacefully at Watts's Jordan Downs Housing Project: "That ole fool Bush think we as dumb as Saddam. Land Marines in Compton and get hisself re-elected. But this ain't Iraq. This is Vietnam, Jack."[31]

Having taken place in an environment closer in its economy and demographics to Baghdad than say La Jolla, the King Incident could not be enframed within the picture of a New World Order. As L.A. burned in May of 1992, as a protest against these unjust police actions, the Rodney King incident reanimated questions about the legality of events justified in the name of the national security dating as far back as Hiroshima.[32] The images of a city burning in protest against police brutality seemed in retrospect a response to the official representation of Baghdad, as the appropriate staging ground for U.S. prominence in the New World Order. [33] Like Hiroshima, L.A. represented one of those cities designated by nuclear strategists as expendable. Images of police brutally clubbing Rodney King recalled a residual series of related images left over from police actions in Vietnam, Korea, Panama, Grenada, and the Persian Gulf. If Baghdad had 
been bombed to demonstrate U.S. technological superiority at the outset of a New World Order, the burning of buildings in South Central Los Angeles inaugurated a counter demonstration. It raised important questions that recalled the related moral dilemmas attending the decision in the name of international security (and an earlier New World Order) to drop the atomic bombs on Hiroshima and Nagasaki at the end of World War II. Whereas the Bush administration had aspired to divert attention away from just such urgent moral dilemmas as these, the aftermath of the Cold War has returned the nation to them as an unfinished collective task.

\section{Donald E. Pease \\ Dartmouth College \\ Nova Scotia}

Surface Page d'Acceuil/Home Page

[1]The best available critique of official coverage of the war can be found in Douglas Kellner's The Persian Gulf TV War (Boulder, CO: Westview Press, 1992).

[2]In "Bombing Logic," Marxism Today, March 1991, p. 46, Dick Hebidge has cogently analyzed the official coverage in terms of the displacement of critical observation with a spectacle of consensus. For an example of a thoroughly post-modernist reading of the Persian Gulf War see Jean Baudrillard's "La Guerre du Golfe n'a pas eu lieu," Liberation, March 29, 1991.

[3]This documentary account appears in Christopher Norris's Uncritical Theory: Postmodernism, Intellectuals and the Gulf War (Amherst: University of Massachusetts Press, 1992): 110-11.

[4]George Mariscal has described this counter memory succinctly: "The violence perpetrated against Rodney King cannot be disassociated from the massive destruction wrought by the United States Government against the Iraqi people." George Mariscal, "In the Wake of the Gulf War: Untying the Yellow Ribbon," Cultural Critique, 19 (Fall 1991): 114.

[5]This account of Reaganism was strongly influenced by Stuart Hall's "The Toad in the Garden: Thatcherism among the Theorists," in Marxism and the Interpretation of Culture, ed. Nelson and Grossberg, (Urbana: University of Illinois Press, 1988): 35-58. 
[6]In Homi Bhabha, "Of Mimicry and Man: The Ambivalence of Colonial Discourse," October 28 (1988): 129.

[7]Jacques Derrida, "No Apocalypse, Not Now (full speed ahead, seven missiles, seven missives)," Diacritics, 14;2 (1984): 23.

[8]In "Sexuality in the Gulf War: Did You Measure Up," Genders 13 (Spring 1992): 3. Abouali Farmanfarmaian refers to the Gulf War as "Hiroshima on the Tigres" to call attention to the usage of the "just war" trope used to justify both events. Further evidence of this linkage can be found in Cal Thomas's "A Time to Think Nuclear," Boston Globe, February 7, 1991: "The United States should use tactical nuclear weapons to... save the lives of American and allied fighters."

[9]George Bush, January 28, 1992, State of the Union Address.

[10]In the same State of the Union Address, Bush connected U.S. victory in the Gulf with an appeal for the funding of S.D.I. "to protect our country from limited nuclear missile attacks... too many people in too many countries have access to nuclear arms."

[11]Dean MacCannell, "Baltimore in the Morning... After: On the Forces of Post-Nuclear Leadership," Diacritics, 14 (Summer 1984): 41.

[12]Guy Debord, The Society of the Spectacle (Detroit: Black and Red Unauthorized Translation, 1970).

[13]Michael Paul Rogin, "Make My Day," Spectacle as Amnesia in Imperial Politics, Representations 29 (Winter 1990): 116-17.

[14]Paul Virilio, Nuclear Democracies (New York: Semiotexte, 1991): 77.

[15]For a somewhat different account of the way in which this understanding of the Cold War narrative functioned in the Construction of the Americanist Canon, see Donald E. Pease, "Moby Dick and the Cold War," The American Renaissance Reconsidered, ed. Walter Michaels and Donald E. Pease (Baltimore: Johns Hopkins University Press, 1985): 115-17.

[16]Marita Startkin, "The Wall, The Screen and the Image: The Vietnam Veteran's Memorial," Representations 35 (Summer 1991): 137-38.

[17]The hostages who had been held captive during the last days of Carter's presidency supplied the mythological relay connecting the Vietnam Veterans 
to the Desert Stormers. See Farmanfarmaian, "Sexuality in the Gulf War," $14-17$.

[18]W. J. T. Mitchell, "The Violence of Public Art: Do the Right Thing," Critical Inquiry 16 (Summer 1990): 888.

[19]John Hellman, American Myth and the Legacy of Vietnam (New York: Columbia University Press, 1986): 153.

[20]For a more expansive overview of the literature of the Vietnam War, see my entry on "The Vietnam War" in The Reader's Encyclopedia of American Literature, ed. George Perkins (New York: Harper's, 1991).

[21]Noam Chomsky, "On War Crimes," in At War with Asia (New York: Pantheony, 1970): 298-99.

[22]Jean-Paul Sartre, On Genocide (Boston: Beacon Press, 1968): 81 -82.

[23]Robert Jay Lifton, The Future of Immortality and Other Essays for a Nuclear Age (New York: Basic Books, 1987): 58, 71-72.

[24]See Lifton, 31-73.

[25]Department of State, Current Policy, No. 869.

[26]In an interview with Mojtba Sadria, "The United States, Japan, and the Gulf War," published in Monthly Review 43 (April 1992), Doug Lummis spelled out this Pentagon strategy with remarkable precision: "The war had to be staged in such a way as to seem unambiguously just, with all the law and justice on the U.S. side, and it had to be winnable, which as they learned from the war in Vietnam, means that it had to be short [...] propaganda was Second-World-War language [...] Their hope was clearly that by reenacting the Second World War, the society could become as strong and healthy and dominant in the world again as it was just before the Cold War began."

[27]The identification President Bush ritualistically adduced between Saddam Hussein's "rape of Kuwait" and Adolph Hitler's invasion of Czechoslovakia fostered this association, and the administration's stakes in this representation: an imaginative re-investment of the symbolic moral and political inheritance of the Second World War onto a Middle Eastern topography previously the source of hostage and oil crises, religious wars, territorial disputes and Irangate. 
[28]When such byproducts of the forty-five years of weapons build up as smart bombs and Patriot missiles hit their targets, a civilian population (in Israel) was in fact defended against possible nuclear attack, and, as a consequence, the U.S. spectator public was encouraged to recognize the usage to which Cold War history could be put in the explanation of Middle Eastern History.

[29]For different accounts of the psychology informing the government officials who fostered this understanding, see The Political Psychology of the Gulf War: Leaders, Publics and the Process of Conflict, ed. Stanley A. Renshon (Pittsburgh: University of Pittsburgh Press, 1993).

[30]In this account of an effective historical counter-memory, I have drawn upon Louis Althusser's notion of an "expressive totality" to explain how what I have called "critical witnessing" can detotalize the cold war's overdetermination of historical eventuation through the triggering of the alternative historical associations the cold war binarism repressed only partly. See Reading Capital, trans. Ben Brewster (London: New Left Books, 1970).

[31]Mike Davis, L.A. Was Just the Beginning: Urban Revolt in the United States: A Thousand Points of Light (Westfield: Open Magazine, Pamphlet \#20, 1992): 5, 7.

[32]In this focusing on race as the category through which to activate a chain of substitute memories, I do not intend the suppression, but the complication of the "gendered" and "classed" reading of the war's mode of production.

[33]For an analysis of the economic status of Los Angeles as a Third World city, see David Rieff, Los Angeles: Capital of the Third World (New York: Simon and Schuster, 1991). 